\title{
Pengaruh Gaya Kepemimpinan Transformasional dan Lingkungan Kerja Terhadap Kepuasan Kerja Pegawai Generasi Milenial Kementerian Perdagangan
}

\author{
${ }^{1}$ Wahyuningsih, ${ }^{2}$ Niko Sudibjo \\ ${ }^{1}$ Fakultas Ekonomi dan Bisnis, Universitas Pelita Harapan, Indonesia \\ ${ }^{2}$ Fakultas Ilmu Pendidikan, Universitas Pelita Harapan, Indonesia \\ Email : ${ }^{1}$ nining.wahyuningsih2011@gmail.com
}

(Diterima: November 2021; Direvisi: Desember 2021; Dipublikasikan: Januari 2022)

\begin{abstract}
ABSTRAK
Penelitian ini bertujuan untuk mengetahui apakah gaya kepemimpinan transformasional dan lingkungan kerja berpengaruh positif terhadap kepuasan kerja pegawai. Penelitian ini dilakukan pada generasi milenial Kementerian Perdagangan dengan jumlah responden 162 pegawai dengan menggunakan metode non-random sampling dan analisis statistik dengan Partial Least Square Structural Equation Modelling (PLS-SEM). Hasil penelitian menunjukkan bahwa terdapat pengaruh positif dan signifikan gaya kepemimpinan transformasional dan lingkungan kerja terhadap kepuasan kerja pegawai generasi milenial Kementerian Perdagangan. Penelitian ini diharapkan menjadi masukan bagi organisasi untuk dapat mengelola gaya kepemimpinan transformasional dan lingkungan kerja yang lebih baik agar memberikan kepuasan kerja yang lebih besar bagi pegawai khususnya generasi milenial sehingga kinerja pegawai dapat meningkat dan tujuan organisasi tercapai.
\end{abstract}

\section{Kata Kunci: Kepuasan Kerja Pegawai, Gaya Kepemimpinan, Transformasional, Lingkungan Kerja, Generasi Milenial}




\section{PENDAHULUAN}

Berhasilnya sebuah organisasi untuk tercapainya tujuan tidak terlepas dari peranan penting sumber daya manusia di dalamnya. Kementerian Perdagangan merupakan instansi pemerintah dengan tugas membantu Presiden untuk melaksanakan urusan perdangangan. Keberhasilan Kementerian Perdagangan dalam mengemban tugas tersebut harus didukung oleh peran serta seluruh sumber daya manusianya yaitu pegawai Kementerian Perdagangan. Sejalan dengan fokus kerja pemerintah yaitu menjadikan pembangunan sumber daya manusia sebagai prioritas utama, salah satu sasaran strategis Kementerian Perdagangan adalah meningkatkan kapabilitas dari kualifikasi pendidikan, kompetensi, dimensi kinerja dan disiplin pegawai yang tinggi dan pegawai adalah penggerak utama dalam pelaksanaan rencana tersebut.

Kepuasan kerja pegawai adalah faktor penting yang harus diperhatikan untuk mengoptimalkan kinerja dan mencapai sasaran strategis organisasi. Rivai (2006) menyatakan bahwa kepemimpinan, kompensasi finansial, lingkungan kerja, masyarakat, pendidikan, dan partisipasi merupakan faktor yang mempengaruhi kepuasan pegawai. Penelitian sebelumnya oleh Astuti dan Iverizkinawati (2018), Daniati dan Mujiati (2018), Wasistha dan Rahyuda (2018) menemukan bahwa gaya kepemimpinan punya pengaruh positif pada rasa puas kerja dan lingkungan kerja memengaruhi secara signifikan dan berkontribusi pada kepuasan kerja pegawai.
Untuk mendukung data diatas dilakukan wawancara awal terhadap 35 responden generasi milenial. Responden adalah pegawai Kementerian Perdagangan dari lintas unit yaitu 20 orang pegawai merupakan staf pelaksana. Jenis kelamin responden adalah $65 \%$ perempuan dan $35 \%$ laki laki. Rata rata tingkat kepuasan kerja yang disampaikan oleh responden adalah $76 \%$. Sebagai pembanding dilakukan wawancara pada 15 pejabat level koordinator dan subkoordinator untuk mengetahui harapan kepuasan pada pegawai dan rata rata yang didapatkan adalah $89.13 \%$. Terdapat perbedaan yang cukup besar antara kepuasan yang telah dirasakan pegawai dan harapan tingkat kepuasan oleh pimpinan.

Tabel berikut menyajikan nilai indeks kepuasan pegawai terhadap sarana prasarana yang diberikan oleh organisasi:

Tabel 1. Nilai Indeks Kepuasan

Sarana Prasarana di Lingkungan

Kementerian Perdagangan

\begin{tabular}{|c|c|}
\hline Tahun & Nilai \\
\hline 2017 & 76.35 \\
\hline 2018 & 81.33 \\
\hline 2019 & 74.10 \\
\hline 2020 & 75.64 \\
\hline
\end{tabular}

Sumber: Laporan Kinerja

Kementerian Perdagangan

Tabel diatas menunjukkan bahwa indeks kepuasan pegawai terhadap sarana prasarana atau yang merupakan lingkungan kerja fisik pada tahun 2020 mengalami kenaikan dari tahun sebelumnya namun tidak signifikan dan masih turun dari indeks kepuasan tahun 2018 yaitu 81.33. Berdasarkan Laporan Kinerja Kementerian Perdagangan, nilai indeks kepuasan dibawah 76.61 
dikategorikan kurang baik. Kepuasan kerja pegawai dipengaruhi oleh sarana prasarana yang disediakan oleh kantor atau dalam hal ini dapat kita sebut sebagai lingkungan kerja fisik. Lingkungan kerja yang mendukung dan nyaman membuat pegawai merasa puas dan bekerja maksimal (Fathonah dan Utami, 2010). Berdasarkan pernyataan diatas, lingkungan kerja fisik merupakan salah satu faktor penentu untuk kepuasan kerja pegawai. Hasibuan (2007) menyebutkan kepuasan kerja adalah sepasang perasaan menyenangkan dan tidak menyenangkan pegawai terhadap suatu pekerjaan. Menurut Tohardi (2007) faktor pokok penentu kepuasan kerja antara lain adanya kompensasi, gaya kepemimpinan dan motivasi.

Pegawai yang puas pada pekerjaan yang dilakukannya biasanya punya atasan dengan gaya kepemimpinan yang sejalan dengan para pegawainya (Thoha, 2007). Dalam penelitian Arthawan dan Mujiati (2017), Wasistha dan Rahyuda (2018), Daniati dan Mujiati (2018) mengungkapkan yaitu ada kaitannya positif antara gaya kepemimpinan transformasional dan rasa puas kerja pegawai. Menurut Maulizar (2012) memberikan motivasi pada pegawai untuk bekerja mencapai sasaran organisasi kemudian memberikan peningkatan kepuasan kebutuhan pegawai lebih tinggi merupakan ciri gaya kepemimpinan transformasional.

Lingkungan kerja yang sesuai akan membuat pegawai bekerja baik, mencapai hasil yang optimal dan merasa puas dengan pekerjaannya (Sedarmayanti, 2011). Sebagaimana penelitian terdahulu oleh Fathonah dan Utami (2013), Daniati dan Mujiati (2018), Siagian dan Khair (2018) menyatakan bhawa terdapat pengaruh ya ng positif dari lingkungan kerja pada rasa puas kerja pegawai.

Jumlah keseluruhan pegawai Kementerian Perdagangan dengan status Pegawai Negeri Sipil adalah 2691 pegawai dimana lebih dari 50\% didominasi oleh pegawai generasi $\mathrm{Y}$ atau generasi milenial yaitu sebanyak 1457 pegawai $(54 \%)$. Sisanya adalah generasi baby boomers $4 \%$, generasi $X$ 39\% dan generasi Z 3\%. Generasi $Y$ adalah angkatan kerja yang mendominasi kebutuhan sumberdaya manusia pada saat sekarang ini. Manajemen sumberdaya manusia penting supaya organisasi dapat memastikan keberlanjutan ketersediaannya dalam mengisi lingkungan kerja yang efektif.

Dominasi generasi Y juga dapat diartikan bahwa generasi $\mathrm{Y}$ adalah penentu keberhasilan organisasi dalam beberapa tahun kedepan. Generasi Y mempunyai kekhasan karakter dan etika kerja yang berbeda dengan generasi sebelumnya (McGuire, Tudnem, Hutchings, 2007) dalam Octaviani $\mathrm{H}$ dan Hartijasti.Y (2016). Generasi Y memiliki tuntutan lebih besar terkait lingkungan kerja baik berupa sistem kompensasi dan tunjangan, teknologi serta umpan balik.

Nilai kerja yang dimiliki generasi milenial (Y) adalah lingkungan kerja (Kowske, Rasch, Wiley, 2010). Ketika mereka tidak mendapatkan sesuai yang diharapkan maka akan memengaruhi kepuasan dan kinerja pegawai tersebut. Organisasi mengalami 
perkembangan, teknologi yang digunakan semakin tinggi, hal ini membuat pekerjaan semakin luas dan sering terjadi perubahan yang harus dirasakan oleh pegawai. Sehingga selain lingkungan kerja yang mendukung diperlukan adanya gaya kepemimpinan yang baik untuk memastikan pegawai bekerja dengan baik juga.

Gaya kepemimpinan dan lingkungan kerja dirasa cukup memberikan pengaruh pada aktivitas dalam perusahaan atau organisasi. Lingkungan kerja yang nyaman berkontribusi positif bagi terselenggaranya berbagai aktivitas kerja dengan mudah. Penelitian Astuti dan Iverizkinawati (2018) menyatakan bahwa dengan memberikan beragam fasilitas dan motivasi dalam wujud perhatian yang serius pada lingkungan kerja dan sarana penunjang bagi pegawai dalam meningkatkan kreativitas bekerja serta memberikan arahan dengan gaya kepemimpingan yang memotivasi pegawai adalah prioritas yang dapat dilakukan untuk memberikan kepuasan kerja pegawai pada tingkat yang lebih tinggi. Melihat nilai kepuasan kerja pegawai yang masih berbeda dengan tingkat harapan kepuasan kerja oleh pimpinan organisasi dan nilai indeks kepuasan terhadap linkungan kerja yang cenderung dalam kategori kurang baik dalam lima tahun terakhir, hal ini yang menjadi permasalahan untuk dilakukan penelitian pada rasa puas kerja pegawai Kementerian Perdagangan berdasarkan gaya kepemimpinan transformasional dan lingkungan kerja.
TINJAUAN PUSTAKA DAN PENGEMBANGAN HIPOTESIS

\section{Kepuasan Kerja Pegawai}

Kepuasan

kerja

menggambarkan perasaan positif terkait pekerjaan diperoleh dengan cara melakukan evaluasi pada karakteristiknya (Robbins dan Judge, 2015). Kepuasan (rasa puas) kerja yaitu unsur penting dari karyawan dan punya pengaruh pada yang karyawan rasakan (Ozer dan Gunluk, 2010). Menurut Setiawan (2009) rasa puas kerja adalah faktor penting dalam memperoleh hasil kerja secara optimal, saat karyawan merasa puas saat bekerja maka dia nantinya dapat bekerja maksimal mengerahkan segala kemampuan untuk menyelesaikan pekerjaannya. Banyaknya aspek pekerjaan yang selaras dengan yang diinginkan individu maka membuat rasa puasnya semakin tinggi begitupula kebalikannya sebab rasa puas bekerja bersifat individual (Noor, 2013). Daniati dan Mujiati (2018) menyebutkan bahwa kepuasan kerja karyawan juga didukung keberadaan pemimpin yang baik, karena menjadi pusat perhatian dan sekaligus contoh bagi pegawainya. Selain gaya kepemimpinan, faktor lain yang cukup memengaruhi pegawai dalam melakukan pekerjaan adalah lingkungan kerja (Gardjito dkk., 2014). Lingkungan kerja yang baik sumber rasa puas pada diri karyawan dan mempengaruhi secara positif pada hal lainnya yang berkaitan dengan kepuasan karyawan misalnya kinerja organisasi atau perusahaan. 
2. Kaitan Gaya Kepemimpinan Transformasional dengan Kepuasan Kerja Pegawai

Makna dari gaya

kepemimpinan adalah kumpulan ciri atau pola perilaku yang dipakai pemimpin organisasi dalam memengaruhi bawahan untuk mencapai sasaran (Rivai, 2014). Gaya kepemimpinan setiap organisasi berbeda beda dipengaruhi oleh sistem organisasi, jumlah pegawai serta tujuannya. Sebuah jenis gaya kepemimpinan yaitu gaya kepemimpinan transformasional. Gaya kepemimpinan ini punya empat aspek yaitu inspirational motivation (motivasi inspirasional), idealized influence (karismatik), individualized consideration (perhatian secara individual), dan intellectual stimulation (stimulasi intelektual). Apabila empat aspek tersebut terpenuhi maka akan mendukung pegawai bekerja keras, menambah produktivitas, memperoleh kepuasan lebih tinggi sehingga dapat meningkatkan efektivitas organisasi, menurunkan tingkat ketidakhadiran dan meminimalkan turnover pegawai (Robbins dan Judge, 2008) dalam Wasistha dan Rahyuda (2018). Penelitian yang dilakukan pada sebuah lembaga mengungkapkan bahwa perilaku kepemimpinan transformasional punya keberpengaruhan positif pada rasa puas kerja (Daniati dan Mujiati 2018; Wasistha dan Rahyuda 2018). Sutrisno (2009) menyatakan bahwa kompensasi, komunikasi, gaya kepemimpinan, kesempatan untuk maju, keamanan kerja, lingkungan kerja termasuk fasilitas, faktor dalam pekerjaan itu sendiri dan aspek sosial dalam pekerjaan yaitu beberapa faktor yang memengaruhi rasa puas kerja pegawai. Gaya kepemimpinan yang diterapkan perlu diperhatikan dengan baik untuk menunjang terwujudnya rasa puas bekerja pegawai yang nantinya membantu peningkatan kinerja produktivitas dan organisasi. Beberapa penelitian lainnya yang menunjukkan adanya pengaruh positif kepemimpinan transformasional pada rasa puas kerja pegawai (Sitompul dan Mujiati 2015; Wiranata dan Mudiartha 2016, Artawan dan Mujiati 2017; Siagian dan Khair 2018; Putra dan Surya 2020). Dari penelitian dan pernyataan tersebut maka usulan hipotesis pertamanya yaitu:

$\mathrm{H}_{1}$ : Gaya kepemimpinan transformasional berpengaruh positif terhadap kepuasan kerja pegawai.

3. Kaitan Lingkungan Kerja dengan Kepuasan Kerja Pegawai

Lingkungan kerja adalah kondisi yang menyangkut segi fisik dan psikis (Wursanto, 2009). Menurut Sedarmayanti (2012) bahwa lingkungan kerja fisik berupa ruang kerja nyaman dengan suhu udara sehat, warna ruangan sesuai, pencahayaan cukup, dan kondisi keaman terjamin, penunjang kepuasan kerja. Pegawai akan bekerja maksimal jika merasa puas dengan lingkungan kerja yang memberikan kenyamanan dan dukungan (Robbins dalam 
Fathonah dan Utami, 2010). Berdasarkan pernyataan tersebut lingkungan kerja yaitu sebuah faktor penentu bagi rasa puas kerja pegawai. Nitisemito (2008) mengatakan lingkungan kerja yaitu segala yang terdapat di lingkungan pekerja yang berpengaruh kepada pekerja itu untuk melaksanakan tugasnya. Lingkungan kerja baik apabila pegawai dapat melaksanakan pekerjaannya dengan tetap merasa sehat, optimal, nyaman dan aman. Lingkungan kerja fisik, interaksi antara atasan dan bawahan, hubungan antar rekan kerja adalah bagian dari lingkungan kerja yang memengaruhi para pegawai dalam menjalankan tugas dan pekerjaannya dengan maksimal. Beberapa penelitian terdahulu sebagian besar mengemukakan adanya hubungan yang positif antara lingkungan kerja terhadap kepuasan kerja pegawai (Rasool 2014; Antari dan Suwandana 2016; Cahyanto dan Mudiartha 2016; Daniati dan Mujiati 2018;). Dari penelitian dan pernyataan tersebut sehingga hipotesis kedua yang diajukan adalah:

\section{$\mathrm{H}_{2}$ : Lingkungan kerja} berpengaruh positif terhadap kepuasan kerja pegawai.

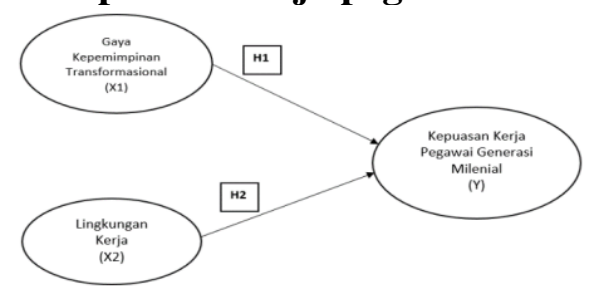

Gambar 1. Model Penelitian

\section{METODE PENELITIAN}

Penelitian ini memiliki tujuan menguji hipotesis pengaruh gaya kepemimpinan transformasional, dan lingkungan kerja terhadap kepuasan kerja pegawai generasi milenial Kementerian Perdagangan. Populasi responden adalah pegawai generasi milenial pada Kementerian Perdagangan dengan status Pegawai Negeri Sipil (PNS). Pengumpulan data dengan penyebaran kuesioner kepada PNS generasi milenial. Rentang usia responden 26 sampai dengan 43 tahun (kelahiran tahun 1977 sampai dengan 1994). Jumlah PNS generasi milenial Kementerian Perdagangan yaitu 1.457 pegawai. Penarikan sampel dengan teknik non random sampling yaitu accidental sampling dan untuk penetapan banyaknya sampel menggunakan rumus Slovin berikut:

$$
n=\frac{N}{1+N(e)^{2}}
$$

Keterangan

$\mathrm{n}=$ jumlah sampel/jumlah responden, $\mathrm{N}=$ jumlah populasi,

$\mathrm{E}=$ Presentase tingkat toleransi kesalahan.

Berdasarkan rumus penghitungan tersebut didapatkan besaran sampel 93.58 atau jumlah minimal sampel adalah 94 orang responden dengan tingkat error $10 \%$. Penelitian ini memperoleh responden sebanyak 162 pegawai yang bekerja pada Kementerian Perdagangan kantor pusat, daerah dan perwakilan luar negeri.

Pengukuran item kuesioner pada penelitian ini menggunakan skala likert 5 poin yaitu poin 5 untuk sangat setuju, poin 4 untuk setuju, cukup setuju pada poin 3 , poin 2 untuk tidak setuju dan sangat tidak setuju pada poin 1. Menggunakan PLS-SEM dengan program SmartPls 3.0 sebagai alat analisis statistik. 
Masing masing variabel $\mathrm{X}$ dan $\mathrm{Y}$ diadaptasi dari penelitian Daniati dan Mujiati (2018); Wasistha dan Rahyuda (2018); Khair dan Siagian (2018); dan Astuti dan Iverizkinawati (2018) serta melalui pengembangan skala.

\section{HASIL PENELITIAN}

Karakteristik pegawai Kementerian Perdagangan yang berpartisipasi dalam penelitian berbeda dalam hal jenis kelamin, usia, latar belakang pendidikan dan lama bekerja seperti yang ditampilkan dalam tabel berikut:

Tabel 1. Profil Responden

\begin{tabular}{|l|r|r|}
\hline \multicolumn{1}{|c|}{ Pernyataan } & Jumlah & \multicolumn{1}{c|}{ Persentase } \\
\hline Jenis Kelamin & & \\
\hline Laki laki & 67 & $41.36 \%$ \\
Perempuan & 95 & $58.64 \%$ \\
\hline Usia & & \\
\hline $26-30$ tahun & 20 & $12.35 \%$ \\
$31-35$ tahun & 46 & $28.40 \%$ \\
$>35$ tahun & 96 & $59.26 \%$ \\
\hline Pendidikan Terakhir & & 0 \\
\hline SMA & 0 & $8.0 \%$ \\
D3 & 13 & $39.5 \%$ \\
S1 & 64 & $51.2 \%$ \\
S2 & 83 & $1.2 \%$ \\
S3 & 2 & \\
\hline Lama Bekerja & & $4.94 \%$ \\
\hline$<1$ tahun & 8 & $5.56 \%$ \\
$1-5$ tahun & 9 & $22.22 \%$ \\
5 - 10 tahun & 36 & $67.28 \%$ \\
\hline$>10$ tahun & 109 & \\
\hline
\end{tabular}

Sumber: Hasil Pengolahan Data

\section{A. Outer Model}

\section{Analisa}

outer

model

dilaksanakan

dalam rangka melakukan uji validitas dan reliabilitas konstruk dari tiap variabel dan membuat kepastian yaitu indikator dari sebuah konstruk punya korelasi yang tinggi. Uji korelasi menurut nilai loading factor dan Average Variance Extracted. Ukurannya dirasa mencukupi jika nilai AVE $\geq$ 0.50 dan setiap indikator mempunyai nilai loading factor $\geq$ 0.70 (Hair et al. 2014). Nilai outer loading berkisar 0.4-0.7 masih bisa dipakai selama nilai AVE $\geq$ 0.55. Nilai outer loading tiap indikator dari penelitian ini antara 0.530 dan 0.876 yang menunjukkan yaitu masingmasing indikator valid sebagai pengukur konstruknya.

Tabel 2. Nilai Outer Loading

\begin{tabular}{|c|c|c|c|}
\hline Variabel & \begin{tabular}{|c|} 
Butir \\
Pernyataan
\end{tabular} & Outer Loading & Ket \\
\hline \multirow{12}{*}{\begin{tabular}{|l|} 
Gaya \\
Kepemimpinan \\
Transformasional
\end{tabular}} & GK1 & 0.530 & Valid \\
\hline & GK2 & 0.591 & Valid \\
\hline & GK3 & 0.755 & Valid \\
\hline & GK4 & 0.852 & Valid \\
\hline & GK5 & 0.855 & Valid \\
\hline & GK6 & 0.667 & Valid \\
\hline & GK7 & 0.876 & Valid \\
\hline & GK8 & 0.757 & Valid \\
\hline & GK9 & 0.772 & Valid \\
\hline & GK10 & 0.845 & Valid \\
\hline & GK11 & 0.832 & Valid \\
\hline & GK12 & 0.697 & Valid \\
\hline \multirow{4}{*}{ Lingkungan Kerja } & LK2 & 0.627 & Valid \\
\hline & LK6 & 0.706 & Valid \\
\hline & LKT & 0.769 & Valid \\
\hline & LK8 & 0.724 & Valid \\
\hline \multirow{10}{*}{$\begin{array}{l}\text { Kepuasan Kerja } \\
\text { Pegawai }\end{array}$} & KK7 & 0.628 & Valid \\
\hline & КК8 & 0.707 & Valid \\
\hline & KK9 & 0.748 & Valid \\
\hline & KK10 & 0.743 & Valid \\
\hline & KK11 & 0.731 & Valid \\
\hline & KK13 & 0.801 & Valid \\
\hline & KK14 & 0.809 & Valid \\
\hline & KK15 & 0.696 & Valid \\
\hline & KK16 & 0.531 & Valid \\
\hline & KK17 & 0.547 & Valid \\
\hline
\end{tabular}

Sumber: Hasil Pengolahan Data

Uji validitas selanjutnya adalah uji discriminant validity. Dengan memakai kriteria FornellLarcker yaitu nilai akar kuadrat AVE harus melebihi nilai hubungan antar konstruk (Hair et al., 2014). Data pada tabel 3 merupakan nilai AVE untuk setiap variabel dari hasil analisis terakhir dan perolehan nilai dari pengujian instrumen ini telah dinyatakan valid. Nilai AVE untuk semua variabel berada sesuai dengan 
yang dipersyaratkan yaitu 0,5 (range 0.501 s.d. 0.577) maka telah memenuhi convergent validity.

Tabel 4 berikut menyajikan analisis diskriminan sesuai kriteria Fornel dan Larcker yaitu nilai akar kuadrat melebihi nilai hubungan antar konstruk. Hasil

Tabel 3. Nilai Average Variance Extracted

\begin{tabular}{|l|c|}
\hline \multicolumn{1}{|c|}{ Variabel } & $\begin{array}{c}\text { Average } \\
\text { Variance } \\
\text { Extrated } \\
\text { (AVE) }\end{array}$ \\
\hline Gaya Kepemimpinan Transformasional & 0.577 \\
\hline Lingkungan Kerja & 0.501 \\
\hline Kepuasan Kerja Pegawai & 0.502 \\
\hline
\end{tabular}

Sumber: Hasil Pengolahan Data

perhitungannya disajikan dibawah ini:

Tabel 4. Hasil Uji Validitas Diskriminan

\begin{tabular}{|l|r|r|r|}
\hline \multicolumn{1}{|c|}{ Konstruk } & $\begin{array}{c}\text { Gaya } \\
\text { Kepemimpinan } \\
\text { Transformasional }\end{array}$ & $\begin{array}{c}\text { Kepuasan } \\
\text { Kerja } \\
\text { Pegarai }\end{array}$ & $\begin{array}{c}\text { Lingkungan } \\
\text { Kerja }\end{array}$ \\
\hline $\begin{array}{l}\text { Gaya } \\
\text { Kepemimpinan } \\
\text { Transformasional }\end{array}$ & $\mathbf{0 . 7 6 0}$ & & \\
\hline $\begin{array}{l}\text { Kepuasan Kerja } \\
\text { Pegawai }\end{array}$ & 0.690 & $\mathbf{0 . 7 0 8}$ & \\
\hline Lingkungan Kerja & 0.566 & 0.611 & $\mathbf{0 . 7 0 8}$ \\
\hline
\end{tabular}

Sumber: Hasil Pengolahan Data

Selanjutnya menguji reliabilitas konstruk dilaksanakan melalui mengamati nilai composite reliability. Suatu variabel dinyatakan reliabel apabila nilai CR memenuhi yaitu harus lebih besar dari 0.7 (Ghozali \& Latan, 2015).

Hasilperhitungan composite reliability seperti pada tabel berikut:

Tabel 5. Tabel Nilai Composite Reliability

\begin{tabular}{|l|r|}
\hline \multicolumn{1}{|c|}{ Konstruk } & \multicolumn{1}{c|}{$\begin{array}{l}\text { Composite } \\
\text { Reliability }\end{array}$} \\
\hline Gaya Kepemimpinan Transformasional & 0.941 \\
\hline Kepuasan Kerja Pegawai & 0.916 \\
\hline Lingkungan Kerja & 0.800 \\
\hline
\end{tabular}

Sumber: Hasil Pengolahan Data

\section{B. Inner Model}

R-Square $\quad\left(\mathrm{R}^{2}\right) \quad$ adalah pengukuran untuk mengetahui seberapa besar konstruk independen menjelaskan konstruk dependen. Diperoleh pengukuran $\mathrm{R}^{2}$ pada penelitian ini adalah 0.547 atau 54,7\%, artinya konstruk kepuasan kerja dipengaruhi oleh konstruk gaya kepemimpinan transformasional dan lingkungan kerja sebesar $54,7 \%$, sisanya dijelaskan atau dipengaruhi oleh konstruk lain sebesar $45,3 \%$.

Tabel 6. Tabel Nilai R-square $\left(\mathrm{R}^{2}\right)$

\begin{tabular}{|l|l|}
\hline Konstruk & R Square \\
\hline $\begin{array}{l}\text { Kepuasan Kerja } \\
\text { Pegawai }\end{array}$ & 0.547 \\
\hline
\end{tabular}

Sumber: Hasil Pengolahan Data

Untuk menguji hipotesis, dilakukan dengan melihat nilai koefisien jalur, uji $\mathrm{t}$ (t-test) dan $\mathrm{p}$ value karena penelitian ini menggunakan sampel sebagai data atau sensus. Ketiga nilai tersebut dapat dilihat sebagai berikut:

Tabel 7. Hasil Pengujian Hipotesis

\begin{tabular}{|l|c|c|c|c|}
\hline \multicolumn{1}{|c|}{ Hipotesis } & $\begin{array}{c}\text { Koefisien } \\
\text { Jalur }\end{array}$ & Uji t & $\boldsymbol{p}$-value & Arah \\
\hline $\begin{array}{l}\text { H1: Gaya kepemimpinan } \\
\text { berpengaruh positif } \\
\text { terhadap kepuasan kerja } \\
\text { pegawai }\end{array}$ & 0.506 & 7.558 & 0.000 & Positif \\
\hline $\begin{array}{l}\text { H2: Lingkungan kerja } \\
\text { berpengaruh positif } \\
\text { terhadap kepuasan kerja } \\
\text { pegawai }\end{array}$ & 0.325 & 4.621 & 0.000 & Positif \\
\hline
\end{tabular}

Sumber: Hasil Pengolahan Data

Tabel diatas menginformasikan bahwa arah koefisien jalur untuk kedua konstruk eksogen adalah positif sesuai dengan hipotesis. Konstruk yang terdominan memberi pengaruh kepuasan kerja pegawai milenial adalah gaya kepemimpinan transformasional dengan nilai 0.506 dan diikuti oleh lingkungan kerja dengan nilai 0.325 . Berdasarkan nilai uji t (7.558 dan 4.621) yaitu lebih tinggi dari 1.96 dan p-value yang lebih rendah dari 0.05 (0.000 dan 0.000) maka semua konstruk signifikan karena punya nilai uji $\mathrm{t}$ 
lebih besar dari 1.96 dan p-value lebih kecil dari 0.05 .

Gambar di bawah merupakan hasil output outer model dari aplikasi PLS-SEM yang menunjukkan nilai $\mathrm{R}^{2}$ kepuasan kerja pegawai sebesar 0.547. Nilai outer loading berkisar antara 0.707 hingga 0.809 . Sedangkan nilai koefisien untuk setiap jalurnya sebesar 0.503 untuk gaya kepemimpinan transformasional dan 0.325 untuk lingkungan kerja.

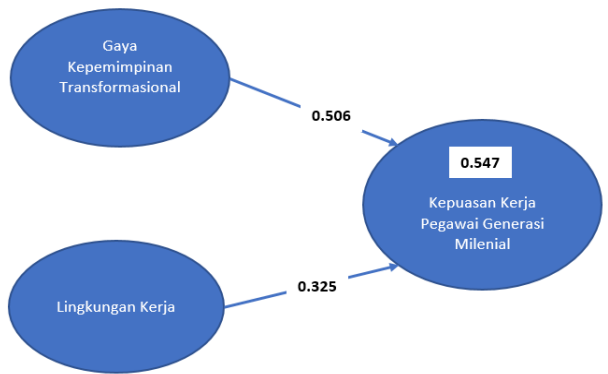

Gambar 2. Hasil analisis outer model Sumber: Hasil Pengolahan Data

\section{PEMBAHASAN}

Hasil olah data menyebutkan
yaitu gaya kepemimpinan transformasional punya pengaruh positif pada rasa puas kerja pegawai dengan nilai koefisien jalur sebesar 0.506 dan berarah positif. Hasil ini sesuai dengan penelitian terdahulu dari Sitompul dan Mujiati (2015), Wiranata dan Mudiartha (2016), Artawan dan Mujiati (2017), Daniati dan Mujiati (2018); Siagian dan Khair (2018); Wasistha dan Rahyuda (2018); Putra dan Surya (2020). Semakin ideal dan sesuai atau tingginya dimensi gaya kepemimpinan transformasional, maka semakin tinggi kepuasan kerja pegawai.

Hipotesis berikutnya dengan hasil koefisien jalur 0.325 dan berarah positif maka lingkungan kerja berpengaruh positif terhadap kepuasan kerja pegawai diterima. Pernyataan ini didukung oleh beberapa penelitian yang lalu oleh Cahyanto dan Mudiartha (2016), Antari dan Suwandana (2016), Daniati dan Mujiati (2018). Semakin nyaman lingkungan kerja yang disediakan oleh organisasi akan meningkatkan kepuasan kerja pegawai.

Arah koefisien jalur kedua hipotesis adalah positif atau bergerak searah dengan konstruk yang paling tinggi adalah gaya kepemimpinan transformasional diikuti oleh lingkungan kerja. Oleh karena itu, organisasi perlu memperhatikan konstruk gaya kepemimpinan sebagai prioritas dalam meningkatkan kepuasan kerja pegawai. Ketika organisasi mampu memiliki pemimpin yang mempunyai gaya kepemimpinan transformasional yang diimplementasikan dengan baik, maka akan berdampak kepada kepuasan kerja pegawai. Namun demikian organisasi juga perlu memperhatikan lingkungan kerja mengingat konstruk tersebut juga memiliki pengaruh langsung pada kepuasan kerja pegawai.

\section{PENUTUP}

\section{Kesimpulan}

Berdasarkan hasil analisis data dapat disimpulkan bahwa gaya kepemimpinan transformasional berpengaruh positif terhadap kepuasan kerja pegawai generasi milenial Kementerian Perdagangan. Begitupula lingkungan kerja memberikan pengaruh yang positif terhadap kepuasan kerja pegawai generasi milenial Kementerian Perdagangan. 


\section{Keterbatasan Penelitian Dan Saran Untuk Penelitian Berikutnya}

Penelitian ini hanya dilakukan pada Kementerian Perdagangan, satu instansi Pemerintah dan tidak mengukur konstruk lain yang mempengaruhi kepuasan pegawai misalnya kompensasi, stress kerja dan work life balance. Untuk penelitian selanjutnya bisa dilakukan survey atau wawancara pendahuluan untuk mendapatkan konstruk paling berpengaruh bagi pegawai pada obyek penelitian. Model penelitian dapat ditambahkan konstruk yang lain seperti kompensasi mengingat kompensasi berhubungan dengan pendapatan yang sangat berpengaruh terhadap kepuasan kerja pegawai.

\section{DAFTAR PUSTAKA}

Antari, Gusti Ayu Eka Jenani dan Suwandana, I Gusti Made. 2016. Pengaruh Lingkungan Kerja, Keadilan Organisasional, Dan Komitmen Organisasional Terhadap Kepuasan Kerja Karyawan. EJurnal Manajemen Unud, 5(7): 4518-4544.

Arthawan, K. J., \& Mujiati, N. W. (2017). Pengaruh Gaya Kepemimpinan

Transformasional dan Kepuasan Kerja Terhadap Kinerja Karyawan pada LPD Kesiman di Denpasar (Doctoral dissertation, Udayana University)

Astuti, R., \& Iverizkinawati, I. (2019).

Pengaruh

Kepemimpinan dan Lingkungan Kerja terhadap Kepuasan Kerja Karyawan pada PT. Sarana Agro Nusantara Medan. Jurnal
Ilman: Jurnal Ilmu

Manajemen, 6(1).

Bernarto, I., \& Herjany, E. (2018). Pengaruh Lingkungan Kerja, Kepuasan Kerja, dan Stress Kerja Terhadap Komitmen Organisasi Guru TK dan SD. Jurnal Manajemen Indonesia, 18(2), 154-164.

Cahyanto, Babby Dwiki Putra dan Mudiartha Utama, I Wayan. 2016. Pengaruh Komunikasi Organisasi dan Lingkungan Kerja Terhadap Kepuasan Kerja Pada PT. Cakra Transport Utama Jimbaran, Bali. E-Jurnal Manajemen Unud, 5(5): 32483273

Chandra, D. O., Hubeis, A. V. S., \& Sukandar, D. (2017). Kepuasan kerja generasi $\mathrm{X}$ dan generasi $\mathrm{Y}$ terhadap komitmen kerja di Bank Mandiri Palembang. Jurnal Aplikasi Bisnis dan Manajemen (JABM), 3(1), 12-12.

Daniati, N. L. H., \& Mujiati, N. W. (2018). Pengaruh Gaya Kepemimpinan

Transformasional,

Kompensasi, dan Lingkungan Kerja terhadap Kepuasan Kerja Karyawan pada Lpd Kerobokan (Doctoral dissertation, Udayana University)

Fahreza, S. (2019). Analisis Faktor Engagement Karyawan Generasi Milenial pada Perusahaan Berbasis Ekonomi Kreatif.

Fathonah, Siti dan Ida Utami. 2010. Pengaruh Kompensasi, Pengembangan Karir, Lingkungan Kerja dan Komitmen Organisasi terhadap Kepuasan Kerja Pegawai 
Seketariat Daerah Kabupaten Karanganyar dengan Keyakinan diri (Self Efficacy) sebagai Variable Pemoderasi. E-Journal STIE AUB Surakarta. Vol. 1, No. 1, hal. 120.

Gardjito, A.H., M.A. Musadieq, dan G.E Nurtjahjono. 2014. Pengaruh Motivasi Kerja dan Lingkungan Kerja terhadap Kinerja karyawan (studi pada karyawan bagian produksi PT. Karmand Mitra Andalan Surabaya). Jurnal Administrasi Bisnis. 13(1): 1-8.

Ghozali, I. \& Latan, H. (2015). Partial least squares: concepts, techniques and applications using smartpls 3.0 ( $2^{\text {nd }}$ ed.). Semarang:

Diponogoro University Press.

Hasibuan, S.P Malayu. 2007. Manajemen Sumber Daya Manusia. Jakarta: Cetakan 9. PT. Bumi Aksara.

Jain, R. and S. Kaur. 2014. Impact of work environtment on job satisfaction. International Journal of Scientific and Research Publications. 4(1): 18.

Kowske, B. J., Rasch, R., \& Wiley, J. (2010). Millennials'(lack of) attitude problem: An empirical examination of generational effects on work attitudes. Journal of business and psychology, 25(2), 265279.

Laporan Kinerja Kementerian Perdagangan Tahun 2017 diakses dari https://www.kemendag.go.id/id /about-us/strategicplanning/laporan-kinerja- kementerian-perdagangantahun-2017

Laporan Kinerja Kementerian Perdagangan Tahun 2018 diakses dari https://www.kemendag.go.id/id /about-us/strategicplanning/laporan-kinerjakementerian-perdagangantahun-2018

Laporan Kinerja Kementerian Perdagangan Tahun 2019 diakses dari https://www.kemendag.go.id/id /about-us/strategicplanning/laporan-kinerjakementerian-perdagangantahun-2019

Laporan Kinerja Kementerian Perdagangan Tahun 2020 diakses dari https://www.kemendag.go.id/id /about-us/strategicplanning/laporan-kinerjakementerian-perdagangantahun-2020

Maulizar, Musnadi Yunus. 2012. Pengaruh Kepemimpinan Transaksional dan Transformasional Terhadap Kinerja Pegawai Bank Syariah Mandiri Cabang Banda. Jurnal Ilmu Manajemen, 1(1), pp: 113.

Miftah, T. (2010). Prilaku Organisasi. Jakarta: Raja Grafindo Persada. Nitisemito, A. S. (2008). Manajemen Personalia. Jakarta: Ghalia Indonesia.

Octaviani, H., \& Hartijasti, Y. (2016). Pengaruh Person Organization Fit dan Budaya Organisasi terhadap Turnover Intention dengan kepuasan Kerja sebagai variabel Mediator. Jurnal 
Manajemen Indonesia, 16(1), 1-14.

Putra, I. M., \& Surya, I. B. (2020). Peran Mediasi Kepuasan Kerja Pada Gaya Kepemimpinan Transformasional Terhadap Kinerja Karyawan Toyota AUTO 2000 Denpasar. EJurnal Manajemen, 9(2), 405425.

Rivai Zainal, Veithzal. 2014. Kepemimpinan dan Perilaku Organisasi. Jakarta: Raja Grafindo Persada.

Robbins, S.P., and Judge, t.A. 2014. Perilaku Organisasi. Edisi 16. Jakarta: Selemba Empat.

Safitri, A., Wismantari, T., \& Hermawati, V. (2021). Pengaruh disiplin kerja, motivasi kerja, dan kepuasan kerja terhadap kinerja pegawai negeri sipil (PNS) generasi "Y" (kasus pada kementerian perdagangan) (Doctoral dissertation, Universitas Pelita Harapan).

Saputra, I. D. G. A., \& Sudharma, I. N. (2017). Pengaruh Promosi Jabatan, Pelatihan Dan Lingkungan Kerja Terhadap Kepuasan Kerja Karyawan (Doctoral dissertation, Udayana University).

Sedarmayanti. 2001. Sumber Daya Manusia dan Produktivitas Kerja. Mandar Maju: Bandung. Siagian, T. S., \& Khair, H. (2018). Pengaruh Gaya Kepemimpinan
Dan Lingkungan Kerja

Terhadap Kinerja Karyawan

Dengan Kepuasan Kerja

Sebagai Variabel

Intervening. Maneggio: Jurnal Ilmiah

Manajemen, 1(1), 59-70

Sitompul. Asri Ardendy dan Mujiati, $\mathrm{Ni}$ Wayan. 2015. Pengaruh Kepemimpinan

Transformasional dan Kompensasi Finansial Pada Kepuasan Kerja Karyawan PT. Auto 2000 Sanur. E-Jurnal Manajemen Unud, 4(8): 23602379.

Sugiyono. 2013. Metode Penelitian Bisnis (Pendekatan Kuantitatif, Kualitatif dan (R\&D). Bandung: Alfabeta.

Tohardi, Ahmad. 2007. Pemahaman Praktis Manajemen Sumber Daya Manusia. Pontianak: Mandar Maju.

Wasistha, C. G., \& Rahyuda, A. G. (2018). Pengaruh Kompensasi, Gaya Kepemimpinan Transformasional Dan Lingkungan Kerja Fisik Terhadap Kepuasan Kerja Pegawai. E-Jurnal

Manajemen, 7(12), 6901-6931. Wisnawa, I. N. A., \& Dewi, A. S. K. (2020). Gaya Kepemimpinan Transformasional Berpengaruh Terhadap Organizational Citizenship Behaviour dengan Dimediasi Variabel Kepuasan Kerja. E-Jurnal Manajemen, 9(2), 528-552. 